Acta Universitatis Lodziensis

\title{
Zbigniew Przygodzki
}

Uniwersytet Łódzki, Wydział Ekonomiczno-Socjologiczny, Katedra Gospodarki Samorządu

Terytorialnego,zbigniew.przygodzki@uni.lodz.pl

\section{Ignacy Waleski}

Uniwersytet Łódzki, Wydział Ekonomiczno-Socjologiczny, Katedra Gospodarki Samorządu Terytorialnego, ignacy.waleski@gmail.com

\section{Szacowanie wartości trudnego dziedzictwa kulturowego. Wycena dóbr nierynkowych metodą deklarowanych preferencji na przykładzie modernistycznego kompleksu biurowo-handlowego}

\begin{abstract}
Streszczenie: Przedmiotem badań jest trudne dziedzictwo, będące spuścizną okresu wpływu sowieckiego w Polsce (1945-1989). Architektura z czasów PRL obecna jest w każdym polskim mieście - w zakresie funkcji mieszkaniowych, kulturowych, gospodarczych, użyteczności publicznej i innych. Przez dziesięciolecia budowle te dewaluowały się zarówno w rozumieniu fizycznym, jak i moralnym. Coraz częściej w dyskursie publicznym pojawiają się opinie o konieczności usunięcia tej części historii z krajobrazu polskich miast. Powstaje więc pytanie, czy usuwanie przez zniszczenie lub generalną przebudowę dziedzictwa kulturowego miast jest właściwym kierunkiem ich odnowy.

W opracowaniu zastosowano podejście indukcyjne, przyjmując, iż podstawą wnioskowania będzie celowo wybrany obiekt, mający wyraźne cechy stygmatyzujące oraz właściwości zabytkowe. Podstawowym celem artykułu jest oszacowanie wartości ekonomicznej wybranego obiektu socmodernistycznego, który przez wiele lat pełnił funkcję dominanty w przestrzeni centralnej. Wyzwaniem badawczym w tym zakresie jest zarówno właściwy dobór i adaptacja metody wyceny, jak i interpretacja wyników. Badanie zrealizowano za pomocą metody deklarowanych preferencji (SPM). Przedmiotem badań jest charakterystyczny dla miasta i mieszkańców, arbitralnie wybrany kompleks biurowo-handlowy "Central” w Łodzi. Badanie zrealizowano wśród użytkowników obiektu.
\end{abstract}

Słowa kluczowe: dziedzictwo kłopotliwe, wartość dziedzictwa kulturowego, metoda deklarowanych preferencji, wartości niematerialne dziedzictwa kulturowego, modernizm

JEL: R14, H41, O18 


\section{Wprowadzenie}

Architektura stanowi podstawowy element kompozycji urbanistycznej w miastach. Można przyjąć, że ,głównym celem kompozycji urbanistycznej jest wydobycie, względnie stworzenie piękna w otoczeniu człowieka" (Wejchert, 1984: 96). Nie oznacza to jednak, że architektura przestrzeni promuje wyłącznie budowle doskonałe w kontekście estetycznym - ,piękne domy nie tylko zawodzą w roli gwarantów szczęścia - można im także zarzucić niezdolność do poprawy charakteru ich mieszkańców" (de Botton, 2006: 17). Niemniej zadaniem architektury jest uzmysłowienie człowiekowi, kim jest i kim mógłby być (de Botton, 2006: 17). Architektura ma zdolność odmiany samopoczucia, które w dużej mierze zależy od koloru ścian, kształtu budynków i wnętrz, rodzaju materiałów, z których wykonane są przedmioty, drzwi, okna, ławki, latarnie. W perspektywie historycznej architektura stanowi symbol ludzkiej działalności i świadectwo epoki. Bardzo często kojarzona była z władzą, manifestacją statusu społecznego, ustroju czy ideologii, osiągnięciami cywilizacyjnymi i innowacjami. Budziła zainteresowanie zarówno w kręgach świeckich, jak i religijnych. Podlegała różnorodnym trendom, koncepcjom budowania miast i modzie. Architektura uznawana jest za materialny symbol i świadectwo historii. W większości przypadków uznanie wartości dziedzictwa kulturowego nie budzi kontrowersji. Nikt nie neguje wartości egipskich piramid, zamku krzyżackiego w Malborku czy też Luwru. W Polsce wątpliwości często wywołują natomiast obiekty młodsze, szczególnie te, które silnie związane są ze wstydliwą bądź represyjną drugą połową XX wieku, czasami realnego socjalizmu (Sokołowicz, Przygodzki, 2020). Określenie wartości dziedzictwa kulturowego takich obiektów jest trudne i budzi wiele kontrowersji. Pojęcie trudnego dziedzictwa kulturowego jest dobrze rozpoznane w literaturze przedmiotu. Funkcjonuje ono w kilku perspektywach - w odniesieniu do wstydliwej historii narodu (Banaszkiewicz, 2015: 11), wojen bratobójczych (Dragićević Šešić, Rogač Mijatović, 2014: 10-19), totalitarnej przeszłości i reżimu władzy (Banaszkiewicz, Semik, 2019: 7-13), a nawet estetyki (Ciarkowski, 2017: 17). Okres PRL wywołuje wśród Polaków różne skojarzenia. Często słyszy się głosy zachęcające do „,rozliczenia" się z socjalistyczną historią kraju, nawoływanie do różnego rodzaju aktów dekomunizacji - zarówno w warstwie dziedzictwa niematerialnego (Ustawa o zakazie propagowania komunizmu [...], Dz.U. 2016 poz. 744), jak i w wymiarze materialnym, często bezpośrednio związanym z architekturą (Sokołowicz, Przygodzki, 2020). Architektura modernistyczna jest także niejednoznacznie oceniana w kontekście estetycznym (Starzec, 2015: 66; Borowski, 2016: 62). Dobrą ilustrację skrajnych emocji wywoływanych przez ten typ architektury stanowił do niedawna Pałac Kultury i Nauki w Warszawie - niewątpliwie jeden z najbardziej rozpoznawalnych w Polsce obiektów powstałych w czasach PRL-u. Budynek ten ma unikalną historię, bryłę oraz przesłanie ideologiczne, zalicza się do niekwestionowanych 
symboli miasta i jest rozpoznawalny w całym kraju. Trudno też nie docenić jego wartości estetycznych, a mimo to bagaż właściwości niematerialnych długo deprecjonował wartość jego dziedzictwa kulturowego (Ochkovskaya, Gerasimenko, 2018: 113-127). Aktualnie obiekt wpisany jest do rejestrów zabytków (od 2 lutego 2007 r.) i inicjatywy tego typu zostały znacznie ograniczone, istnieje także sprawniejszy nadzór nad pracami remontowymi, tak aby nie doprowadzić do istotnych zmian w budynku, zatracających jego pierwotny charakter.

Jednak nie wszystkie budynki powstałe w okresie realnego socjalizmu spotyka ten sam los. Niektóre, pomimo unikalnych cech architektonicznych, jak chociażby brutalistyczny dworzec w Katowicach o kielichowej konstrukcji, nie przetrwały próby czasu i zostały wyburzone (Springer, 2011: 129). Inne, na skutek niekontrolowanych remontów i modernizacji, zatraciły swój unikalny charakter, jak na przykład restauracja „Balaton” w Lodzi. A jeszcze inne po prostu niszczeją w zapomnieniu, opustoszałe (Ciarkowski, 2017: 19-25).

Spostrzeżenia te skłaniają do refleksji, iż tego typu degradacja unikalnej i oryginalnej tkanki architektonicznej powinna być powodem do podjęcia aktywnych działań. Okazuje się, że objęcie ochroną konserwatorską często nie wystarcza. Zdarza się nawet, że jest to wręcz stan kłopotliwy dla właściciela nieruchomości, pozbawiający go narzędzi motywujących do ochrony, podkreślający restrykcje (Radzimirska, 2011: 189-200). Zbyt niska świadomość społeczna na temat wartości tych obiektów stwarza swoistą sytuację przyzwolenia społecznego na pozbywanie się tego typu dziedzictwa z krajobrazu miast. Dlatego też ważnym zadaniem jest budowanie świadomości wartości tego typu obiektów, szczególnie gdy duża część z nich nie wymaga jeszcze olbrzymich nakładów finansowych związanych $\mathrm{z}$ odbudową i restauracją. Częściej potrzebują one podstawowych, mało wymagających inwestycji remontowych (Matysiak, Stępniak, 2015: 34). Niemniej identyfikacja wartości materialnej i niematerialnej tego typu obiektów nie jest rzeczą oczywistą. Tak więc, aby w sposób prawidłowy oszacować wartość wybranego obiektu socmodernistycznego, dokonano adaptacji jednej z metod wyceny wartości dziedzictwa kulturowego. Wybrano obiekt, który przez wiele lat pełnił funkcję dominanty w przestrzeni centralnej. Wyzwaniem badawczym w tym zakresie jest zarówno właściwy dobór i adaptacja metody wyceny, jak i poprawność jej przeprowadzenia. Trudność polega przede wszystkim na tym, iż typowe metody rynkowej wyceny nieruchomości pomijać będą w tym przypadku wartości niematerialne wynikające $\mathrm{z}$ dziedzictwa kulturowego (w tym skojarzenia $\mathrm{z}$ trudnym okresem represji). $Z$ drugiej strony najczęściej wykorzystywane metody wyceny obiektów dziedzictwa kulturowego sprawdzają się w przypadku zabytków, które mają niekwestionowane walory turystyczne (Murzyn-Kupisz, 2015: 147-164). 


\section{Dylematy szacowania wartości trudnego dziedzictwa kulturowego}

Kwestię wątpliwości w interpretacji dziedzictwa o kontrowersyjnej przeszłości, kojarzącej się z opresją władzy, określa angielski termin dissonant heritage - dziedzictwo kłopotliwe, trudne. Określenie to może być ściśle powiązane $\mathrm{z}$ „totalitaryzmami", takimi jak komunizm czy faszyzm (Battilani, Bernini, Mariotti, 2018: 1417-1436), ale także z innymi przejawami represji: okupacją czy na przykład handlem niewolnikami (Dann, Seaton, 2001: 1-211). Dziedzictwo kłopotliwe łączy w sobie dwie perspektywy, które stoją w stosunku do siebie w opozycji: uznaje wartość historyczną obiektu i podkreśla jednocześnie negatywną ideologię, która nie musi, lecz może być w prosty sposób promowana za jego pośrednictwem. „Dobra kultury, są czymś, co próbujemy zobiektywizować i objąć bezwarunkową ochroną. Dziedzictwo kłopotliwe jest [...] fazą debaty, namysłu, wynegocjowania, dlaczego i na jakich zasadach warto zatroszczyć się o jak najszerszą część dziedziczonej przez nas spuścizny" (Purchla, 2017: 16; zob. też Dragićević Šešić, Rogač Mijatović, 2014: 10-19). Należy bowiem pamiętać, że kluczową kwestią określającą co jest dziedzictwem, jest jego warstwa niematerialna, czyli sfera pamięci. Dziedzictwo kłopotliwe powinno być obszarem debaty i kontrowersji, jednak powinno być pozbawione aktów barbarzyństwa i agresji (Purchla, 2017: 16), a jego sednem powinno być poprawne rozróżnianie dóbr kultury od dziedzictwa. Dyskusja dotycząca dziedzictwa może toczyć się na różnych płaszczyznach, niemniej jest niezbędna w celu przewartościowania ludzkich doznań, wydobycia wartości, które zostały zaszufladkowanie i skatalogowane pod wstydliwym hasłem. Dyskurs dotyczący dziedzictwa kształtuje percepcję zarówno w sensie materialnym, jak i w wymiarze ideologicznym. Pozwala na zachowanie tożsamości, poczucie trwałości, bezpieczeństwa, dumy i odpowiedzialności. W ten sposób powstają różne rodzaje wartości związane z dziedzictwem kulturowym, również tym kłopotliwym.

Zakres terytorialny kłopotliwego dziedzictwa w kontekście wschodnioeuropejskich krajów postsocjalistycznych ma charakter ponadlokalny i ponadkrajowy. Oznacza to, że tego typu zasoby, które powstawały w ściśle określonym czasie, miejscu i realiach, mają pewne cechy wspólne, niezwiązane z granicami geograficznymi danego kraju (Jász, 2018: 93). Dlatego też obecnie na terenie większości byłych krajów tzw. bloku wschodniego coraz częściej zainteresowanie badaczy i turystów zwracają obiekty z tego okresu. Przedmiotem badań są z jednej strony elementy zagospodarowania przestrzennego wsi i małych miasteczek (Ingerpuu, 2018: 954-966), a z drugiej spuścizna tego okresu obecna w dużych miastach. Doskonałym przykładem mogą tu być budynki administracyjne kołchozów znajdujących się na terenie Estonii. W toku badań nad wartością tego dziedzictwa wiele uwagi skupiła po pierwsze polemika nad wzmacnianiem w świadomości 
społecznej faktu obecności i historii tych obiektów. Z drugiej strony kontrowersje wzbudzały także kwestie adaptacji i wykorzystania tego typu dziedzictwa do realizacji współczesnych funkcji (Ingerpuu, 2018: 954-966). W dużych miastach badania opisywane w literaturze dotyczą często możliwości wykorzystania tych zasobów do kreowania specyficznych produktów turystycznych (dark tourism). Przykładem mogą tu być badania dotyczące zasobów trudnego dziedzictwa kulturowego centrum Bukaresztu (Light, 2000: 145-160).

Interpretacja dziedzictwa kulturowego, w tym dziedzictwa kłopotliwego, jest wieloaspektowa i nie zawsze prosta do jednoznacznego zdefiniowania. Wartość dziedzictwa kulturowego może być bowiem mierzona w wielu skalach. Najczęściej zwraca się uwagę na wartości poznawcze, emocjonalne i symboliczne (Kobyliński, 2011: 25). Wydaje się jednak, że bardzo ważnymi składowymi determinującymi wartość, szczególnie obiektów stosunkowo młodych, jest percepcja wartości finansowej i użytkowej. Niektóre z wartości dziedzictwa kulturowego mają charakter obiektywny i uniwersalny, inne do prawidłowej percepcji wymagają kontekstu kulturowego czy też społecznego odbiorcy dobra. Okazuje się, że kluczową kwestią jest odbieranie danego dobra przez pryzmat tzw. wartości symboliczno-skojarzeniowych (Kobyliński, 2011: 25). Należy przez to rozumieć zdolność do skupiania wokół określonego dobra poczucia przynależności do grupy etnicznej, uczuć patriotycznych, wspólnych idei, religii, wspólnego pochodzenia. Jest to szczególnie ważne w kontekście globalizacji, kiedy granice zaczynają być coraz bardziej rozmyte (Polak, 2018: 1). Potrzeba kultywowania własnych tradycji, historii i pamięć o korzeniach okazują się bardzo ważne. Niemniej w przypadku dziedzictwa okresu PRL-u najważniejszym kontekstem kształtującym wartość dóbr jest sfera świadomości społecznej i doświadczeń własnych (Sokołowicz, Przygodzki, 2020).

Równie ważne jak wartości niematerialne są kwestie stricte estetyczne - wizualne. Nie do przecenienia jest ich znaczenie w kontekście świadectwa kulturowego, artystycznego czy też warsztatowego. Są one bezpośrednim dowodem przeszłości i źródłem poznania. Stąd też przekonanie, z punktu widzenia szeroko rozumianej ochrony zabytków, iż kultura tworzy się na podstawie dóbr, które są cenne dla całej ludzkości, a nie tylko dla wybranej społeczności. Przy tym konieczność ich ochrony wynika także z ich fizycznej nietrwałości (Kobyliński, 2011: 20).

Identyfikacja ekonomicznej wartości dziedzictwa kulturowego jest zatem wielowątkowa i wymyka się sposobom wyceny dóbr rynkowych. Korzystając z dorobku badaczy dziedzictwa kulturowego (Murzyn-Kupisz, 2015) oraz ekonomistów (Fredheim, Khalaf, 2016: 466-481), w tym ekonomistów środowiska (Pietrzyk-Kaszyńska, Czepkiewicz, Kronenberg, 2017: 85-95), a także urbanistów (Costa i in., 2019: 274), można przyjąć, że wartość ekonomiczna dóbr nierynkowych składa się z dwóch zbiorów wartości: użytkowej i pozaużytkowej. Aspekt użytkowy przejawia się w tym, iż konsument danego dobra bezpośrednio z niego korzysta, lub 
ma taką możliwość. Natomiast aspekt pozaużytkowy dotyczy sytuacji, gdy użytkownik danego dobra bezpośrednio z niego nie korzysta, ale czerpie satysfakcję z samego faktu jego istnienia. $O$ ile aspekt użytkowy nie jest trudny do wyjaśnienia, o tyle pozaużytkowy może już stanowić wyzwanie (Sokołowicz, Przygodzki, 2020). Wycena dóbr o charakterze nierynkowym jest stosunkowo innowacyjnym podejściem do ochrony dziedzictwa kulturowego i koordynowania procesów rozwoju na poziomie miast i regionów. Jeszcze kilkadziesiąt lat temu podejście to nie było praktykowane. Pierwsze metody wyceny dóbr nierynkowych powstały przełomie lat pięćdziesiątych i sześćdziesiątych XX wieku (Żylicz, 2008: 8). Wiele z nich odnosiło się do wyceny wartości elementów środowiska naturalnego, a z czasem zaczęły być one adaptowane na inne płaszczyzny i przedmioty badań, w tym elementy dziedzictwa kulturowego (Żylicz, 2008: 8).

Wartość użytkowa obiektów dziedzictwa kulturowego może być zarówno bezpośrednia (np. cena sprzedaży nieruchomości, czynsz, dochód z działalności), jak i pośrednia (odwołująca się do wpływu obiektu na wizerunek miasta, jego prestiżu, a także do jakości zagospodarowania). Wartością pozaużytkową z kolei, transponując powyższe przykłady na obszar rynku nieruchomości, mogą być kwestie spuścizny danego obiektu dla przyszłych pokoleń czy też kwestie stricte estetyczne, łączące się z przyjemnością obcowania z unikalną architekturą, a także wartości związane z tożsamością regionalną, narodową (Borin, Juno-Delgado, 2018). W przypadku oceny jakiegoś dobra, szczególnie takiego, którego wartość jest trudna do oszacowania, pojawiają się liczne wątpliwości. Czy któraś z wartości przeważa? Czy można mówić o racjonalności ekonomicznej obiektu zabytkowego? Odpowiedzi na te pytania nie są łatwe i jednoznaczne. Przede wszystkim trzeba zauważyć, iż często wywierana jest presja ekonomiczna na zabytek - jakoby koniecznie musiał on „na siebie zarabiać”. Oprócz tego często problematyczna jest kwestia użyteczności - czy obiekty takie powinno się eksploatować, czy jednak wyłączyć z „normalnego” użytkowania. Wiele problemów nastręcza również samo ustalenie wartości (Morse-Jones i in., 2008: 134).

W literaturze przywołuje się dwie podstawowe grupy metod wyceny dóbr nierynkowych: pośrednie oraz bezpośrednie (Bosek, Mazurkiewicz, 2015: 150). Metody pośrednie opierają się na tzw. rynkach zastępczych, czyli na preferencjach ujawnionych (Revealed Preference Methods - RPM). Przyjmuje się założenie, że mimo braku występowania danego dobra na rynku, można je powiązać z innym dobrem rynkowym mającym cenę i w ten sposób poznać wartość interesującego nas dobra (Żylicz, 2008: 8). Do metod pośrednich zaliczyć można metody: kosztów prewencji, kosztów zniszczenia, kosztu podróży czy też cen przyjemności (podejście hedoniczne) (Żylicz, 2008: 8). Dla przykładu: metody kosztu podróży użyto w badaniach hiszpańskiego zespołu dóbr o charakterze historyczno-kulturowym (składnikami tej wyceny były: muzeum miasta Burgos, Katedra św. Antonina z Pamiers w Palencji, miasteczko Urueña, a także Iberyjski Festiwal Muzyki 
organowej w regionie Tierra de Campos w prowincji Palencja) (Bedate, Herrero, Sanz, 2004: 101-111). Analizy te służyły identyfikacji skali oddziaływania zasobów dziedzictwa kulturowego na rozwój regionu w zakresie turystyki.

Metod bezpośrednie bazują na tak zwanych preferencjach deklarowanych (Stated Preference Methods - SPM). Polegają one na stworzeniu hipotetycznego rynku, na którym potencjalni konsumenci dokonują wyboru czegoś, co w rzeczywistości nie występuje na rynku i nie podlega wymianie rynkowej. W tym przypadku najczęściej stosuje się metodę wyceny warunkowej, metodę gotowości do zapłaty lub metodę gotowości do przyjęcia rekompensaty (Sokołowicz, Przygodzki, 2020). Metoda wyceny warunkowej polega na uzyskaniu od konsumentów odpowiedzi na pytanie o gotowość do zapłaty za pewne dobro. Chodzi tutaj o koszt, który należałoby ponieść przy realizacji, a także szacunkową i hipotetyczną chęć zapłaty za dane dobro. Metoda ta stosowana była na przykład podczas badań historycznej zabudowy chilijskiego miasta Valdivia, łączącej hiszpańsko-niemieckie wpływy osadnictwa (Báez Montenegro, Niklitschek Huaquin, Herrero, 2009: 97-109). Metoda gotowości do zapłaty polega na zadaniu konsumentowi pytań, ile byłby gotowy zapłacić za określone dobro lub dany poziom usług. Natomiast metoda gotowości do przyjęcia rekompensaty jest trochę podobna do poprzedniej metody, ale respondenci pytani są o minimalną kwotę, jaką chcieliby otrzymać za rezygnację z danego dobra lub za akceptację czegoś dla nich niepożądanego (Żylicz, 2008: 8). Wyzwaniem w stosowaniu tych metod jest dostosowanie i sformułowanie odpowiednich pytań do respondentów, aby uzyskać wiarygodny i pożądany kontekst odpowiedzi. Badania preferencji deklarowanych, wykorzystujące i łączące różne metody badawcze, prowadzili Sokołowicz i Przygodzki. Ich przedmiotem w zakresie identyfikacji wartości kłopotliwego dziedzictwa socmodernizmu były wybrane stacje Warszawskiej Kolei Dojazdowej - WKD (Sokołowicz, Przygodzki, 2020). Warto również zaznaczyć, iż równolegle realizowano komplementarne badania nad identyfikacją wartości stacji WKD w odniesieniu do otoczenia, w którym się znajdują, oparte na analizach percepcji i wrażeń użytkowników (Nowakowska, Guz, Łaszkiewicz, 2020).

\section{Metodologia badań}

Celem badań jest oszacowanie wartości ekonomicznej obiektu kłopotliwego dziedzictwa kulturowego. Operacjonalizując badania, sformułowano hipotezę, którą poddano weryfikacji:

H1: Jeżeli obiekt charakteryzuje się wysokim poziomem użyteczności, to jego wartość pozostaje wysoka pomimo stygmatów kłopotliwego dziedzictwa kulturowego. 
W artykule zastosowano podejście indukcyjne, przyjmując, iż podstawą wnioskowania będzie celowo wybrany obiekt, mający wyraźne cechy stygmatyzujące oraz właściwości zabytkowe. Do badań wybrano obiekt dziedzictwa socmodernistycznego, który przez wiele lat pełnił funkcję dominanty w przestrzeni centralnej miasta. Wyzwaniem badawczym w tym zakresie jest zarówno właściwy dobór i adaptacja metody wyceny, jak i interpretacja wyników. Przedmiotem badań jest charakterystyczny dla miasta, arbitralnie wybrany kompleks biurowo-handlowy „Central” w Łodzi. Jego rozpoznawalność wynika nie tylko z unikalności bryły budynku i symboliki, lecz także z lokalizacji w samym centrum miasta. Badanie zrealizowano za pomocą szacowania wartości metodą bezpośrednią, odwołującą się do preferencji deklarowanych (Stated Preference Methods - SPM). Badania miały charakter sondażowy. Z uwagi na trudność w ustaleniu charakterystyki populacji generalnej dobór respondentów miał charakter przypadkowy. Zabezpieczono udział respondentów w zróżnicowanych grupach wiekowych, zbliżonych do struktury mieszkańców Łodzi. Badanie zrealizowano za pomocą ankiety bezpośredniej wśród użytkowników obiektu. Wzięło w nim udział 102 respondentów, będących częstymi użytkownikami kompleksu biurowo-handlowego „Central”. W badaniu uczestniczyło 53\% mężczyzn i 47\% kobiet. W wieku od 18 do 35 lat było $47 \%$ respondentów, 36\% w wieku 36-64 lata i 17\% powyżej 65 lat. Kwestionariusz ankiety zawierał trzy części. W pierwszej zawarto pytania, których celem była ogólna identyfikacja postrzegania architektury socmodernisycznej wśród użytkowników badanego obiektu, druga dotyczyła bezpośrednio kompleksu biurowo-handlowego „Central”. Celem tej części ankiety było rozpoznanie percepcji obiektu oraz postulatów respondentów w odniesieniu do przyszłości kompleksu. Trzecią część stanowiły pytania dotyczące gotowości respondentów do zapłaty lub partycypacji w kosztach zmiany przeznaczenia i użytkowania obiektu. Ta część stanowiła zasadniczą treść narzędzia badawczego. Zawarto w niej siedem alternatywnych scenariuszy odnoszących się w realnym zakresie do przyszłości obiektu i potencjalnych jego zmian (Tabela 1). W ankiecie sformułowano pytania, w których respondent musiał przyznać punkty w skali 1-7 dla preferowanego kierunku przekształceń kompleksu. Skalę zdefiniowano w taki sposób, że 1 oznaczało najwyższy poziom akceptacji, a 7 brak akceptacji. Oznacza to, że przedziały od 1 do 3 wyrażały pożądany poziom akceptacji działań, ocena 4 oznaczała wyraz niezdecydowania respondenta, natomiast oceny 5-7 wyrażały siłę braku akceptacji działań. Pytania dotyczące poszczególnych scenariuszy zostały połączone z deklarowaną gotowością respondenta (aktualnie użytkownika obiektu) do zapłaty za korzystanie z nowych funkcjonalności obiektu lub partycypowania w kosztach takiego przekształcenia. 
Tabela 1. Potencjalne scenariusze przekształceń obiektu biurowo-handlowego

\begin{tabular}{|c|l|}
\hline Lp. & \multicolumn{1}{|c|}{ Scenariusze } \\
\hline S1 & $\begin{array}{l}\text { Budynek poddany zostaje gruntownemu remontowi, obecna funkcja handlowo-biurowa } \\
\text { pozostaje bez zmian. }\end{array}$ \\
\hline S2 & $\begin{array}{l}\text { Budynek poddany zostaje gruntownemu remontowi, funkcje budynku zostają zmienione } \\
\text { - muzeum. }\end{array}$ \\
\hline S3 & $\begin{array}{l}\text { Budynek poddany zostaje gruntownemu remontowi, funkcje budynku zostają zmienione } \\
\text { - hotel (w tym w systemie aparthotel). }\end{array}$ \\
\hline S4 & $\begin{array}{l}\text { Budynek poddany zostaje gruntownemu remontowi, funkcje budynku zostają zmienione } \\
\text { - funkcja mieszkalna (w tym w mieszkania na wynajem). }\end{array}$ \\
\hline S5 & $\begin{array}{l}\text { Budynek poddany zostaje gruntownemu remontowi, funkcje budynku zostają zmienione } \\
\text { - funkcja kongresowo-wystawiennicza. }\end{array}$ \\
\hline S6 & $\begin{array}{l}\text { Nie zmienia się funkcja i zagospodarowanie nieruchomości. Nie są także podejmowane } \\
\text { gruntowne prace remontowe, jedynie remonty bieżące. }\end{array}$ \\
\hline S7 & $\begin{array}{l}\text { Budynek zostaje zburzony. Nieruchomość sprzedana inwestorowi i wskazane nowe zago- } \\
\text { spodarowanie terenu. }\end{array}$ \\
\hline
\end{tabular}

Źródło: opracowanie własne

\section{Wyniki badań}

Respondenci w większość (56\%) wskazali, że „Central” i tego typu architektura socmodernistyczna jest przede wszystkim symbolem minionych czasów - aż 40\% badanych wprost kojarzył się z opresją czasów PRL. Niemniej 44\% respondentów uważało, że warto ją zachować (połowę tych odpowiedzi formułowali ci, którzy mieli negatywne skojarzenia). Respondenci mieli bardzo dobrą wiedzę na temat historii obiektu, $85 \%$ badanych niemal dokładnie potrafiło określić datę powstania „Centralu”, kolejne 6\% myliło się jedynie o dekadę. Jako ważny symbol Łodzi „Central" postrzegało 59\%, a dla 81\% obiekt ten przywoływał wspomnienia. Około 70\% badanych twierdziło, że obiekt należy zachować bez względu na koszty, własność i przeznaczenie, choć, co ciekawe, nie jest to kompleks, który powszechnie podobał się respondentom. Z kolei 37\% stwierdziło, że lubi formę i styl tego budynku, tyle samo twierdziło przeciwnie, a 26\% nie miało zdania w tej kwestii. Niemniej $60 \%$ badanych uważało obiekt za specyficzny, ciekawy, wyjątkowy. Estetyka nie jest zatem w tym przypadku czynnikiem znacząco wpływającym na wartość przedmiotu badań.

Wstępem do zasadniczej części badania było przedstawienie do akceptacji respondenta działań związanych z obiektem, których celem miałby być generalny remontu „Centralu” i jednocześnie zachowanie istniejącej funkcji biurowo-handlowej ${ }^{1}$. Co ciekawe, pomimo niedawno przeprowadzonego częściowego remontu

1 Taki scenariusz został w rzeczywistości zrealizowany. Badania były natomiast prowadzone w czasie, kiedy obiekt był tylko częściowo wyremontowany i użytkownicy nie mieli 
obiektu handlowego, respondenci w dalszym ciągu uważali za konieczne wyremontowanie całości. Być może jakość remontu nie zmieniła postrzegania budynku. Ponad $69 \%$ ankietowanych uważało, iż pozostawienie obecnie istniejącej funkcji jest najbardziej pożądane (S1 - wykres 1). Scenariusz ten zyskał najwyższy poziom aprobaty spośród zaproponowanego katalogu. Jedynie 17,6\% odpowiadających miało przeciwne zdanie. Wiarygodność tej oceny uzasadnia również zakres deklarowanego włączenia się w finansowanie takiego remontu i przywracania pierwotnych funkcji (przy założeniu, że jest to jedyny, najefektywniejszy i powszechny dla społeczności miasta sposób osiągnięcia takiego celu). W pytaniu podano referencyjną wartość inwestycji na poziomie $21 \mathrm{mln}$ złotych, odwołując się do przykładu podobnego obiektu w Katowicach (wykres 2). Podpowiedzią dla badanych było wskazanie, że gdyby każdy mieszkaniec Łodzi zaangażował się we wsparcie tego działania, to jednokrotnie musiałby przeznaczyć na ten cel 37,5 zł. Warto podkreślić, że średnia wartość zadeklarowana przez respondentów, którzy twierdzili, iż wyraziliby zgodę na wsparcie realizacji takiego scenariusza, była wyższa i wynosiła 42 zł. Z kolei 21,57\% osób nie zadeklarowało żadnej kwoty lub zadeklarowało $0 \mathrm{zł}$. Oznacza to, iż gdyby uwzględnić proporcjonalną do wyników badań liczbę mieszkańców miasta gotowych partycypować w ochronie tego dziedzictwa kulturowego, to uzyskano by kwotę 21583044 zł.

Drugim cieszącym się popularnością scenariuszem był generalny remont obiektu i wprowadzenie do niego funkcji kongresowo-wystawienniczej (S5 - wykres 3). Opinię taką wyraziło $43 \%$ badanych, jednak też stosunkowo dużo osób $-38 \%$ - było przeciwko realizacji takiego scenariusza. W pytaniu podano referencyjną wartość inwestycji na poziomie $40 \mathrm{mln}$ złotych, odwołując się do przykładu budowy nowej hali Międzynarodowych Targów Łódzkich (wykres 4). Podpowiedzią dla badanych było wskazanie, że gdyby każdy mieszkaniec Łodzi zaangażował się we wsparcie tego działania, to jednokrotnie musiałby przeznaczyć na ten cel 32,36 zł. Warto podkreślić, że średnia wartość zadeklarowana przez respondentów, którzy twierdzili, iż wyraziliby zgodę na wsparcie realizacji takiego scenariusza, była wyższa i wynosiła 41,95 zł. 47,06\% osób nie zadeklarowało żadnej kwoty lub zadeklarowało 0 zł (wykres 4). Oznacza to, iż gdyby uwzględnić proporcjonalną do wyników badań liczbę mieszkańców miasta gotowych partycypować w ochronie tego obiektu, to uzyskano by kwotę 15351378 zł. To znacznie mniej niż koszt budowy nowej hali wystawienniczej w odniesieniu do wartości referencyjnej. Tak więc mimo deklaracji wysokiego poziomu poparcia dla realizacji scenariusza S5 jego wycena sugeruje powściągliwość użytkowników w zaangażowaniu w jego realizację.

Prawie co trzeci badany (28\%) uważał, że „Central” to właściwe miejsce, aby przeprowadzić kapitalny remont i wprowadzić funkcje hotelowe ( $\mathrm{S} 3$-wykres 5). Niemniej $62 \%$ respondentów nie zgadzało się na taki rodzaj zagospodarowania.

świadomości, jaka będzie jego przyszłość. 
Wartość obiektu według tego scenariusza okazała się znacznie niższa od pozostałych, zwłaszcza w kontekście cen rynkowych. W tym przypadku poproszono respondentów o deklarację ceny najmu pokoju na dobę hotelową. Badani dysponowali jednocześnie wiedzą, że w bliskim sąsiedztwie cena doby w hotelu o standardzie 2-3 gwiazdki wynosi średnio 190 zł (przyjęta wartość referencyjna). Osoby deklarujące chęć spędzenia doby w tak dostosowanym budynku średnio na ten cel przeznaczyłyby około $163 \mathrm{zł}$ (wykres 6).

Co czwarty respondent (25\%) zwrócił również uwagę, że interesującą alternatywą dla aktualnego stanu obiektu jest generalny remont w kierunku dostosowania obiektu do funkcji mieszkalnej (S4 - wykres 7). Należy też jasno podkreślić, że taka całkowita prywatyzacja przestrzeni spotkała się ze sceptycyzmem $50 \%$ badanych, a aż 25\% nie miało zdania na ten temat. Badani preferujący taką strategię inwestycyjną dla „Centralu” deklarowali jednocześnie zgodę na zakup tam mieszkania za kwotę 5040 zł za m² (wykres 8). Ten poziom deklaracji stawki za $\mathrm{m}^{2}$ powierzchni mieszkania należy uznać za stosunkowo wysoki (respondenci mieli wiedzę o cenie referencyjnej $5500 \mathrm{zł} / \mathrm{m}^{2}$ apartamentowców w sąsiedztwie - Central Park Apartments).

Co piąty respondent (21\%) zgodziłby się, aby „Central” został gruntownie wyremontowany i powstało tam muzeum (S2 - wykres 9), czyli obiekt otwarty o charakterze użyteczności publicznej. Ta strategia budziła jednak poważne wątpliwości 66\% badanych, którzy dostrzegali w takim zachowaniu dużą niegospodarność. Zapytani o to, dlaczego formułują takie odpowiedzi, twierdzili, że to zbyt cenne miejsce w ścisłym centrum miasta, aby na siebie nie zarabiało. Średnia wartość zaangażowania finansowego, jaką mogliby przeznaczyć deklarujący tę strategię respondenci, wyniosła 44,41 zł (wykres 10). Wartość referencyjną 30,45 zł uzyskano w odwołaniu do inwestycji Muzeum Polskiej Wódki w Warszawie (przyjęto deklarowaną wartość inwestycji: $30 \mathrm{mln}$ zł). Oznacza to, iż gdyby uwzględnić proporcjonalną do wyników badań liczbę mieszkańców miasta gotowych partycypować w ochronie tego dziedzictwa kulturowego, to uzyskano by kwotę 16232254 zł.

W przypadku scenariuszy S6 i S7 respondenci zdecydowanie sprzeciwiali się sytuacji, aby budynek pozostawić w aktualnym stanie bez remontu (ok. 80\% odpowiedzi) oraz zdecydowanie sprzeciwiali się jego wyburzeniu i zastąpieniu architekturą innego rodzaju (ok. 90\% odpowiedzi). Zapytano także, jaką konkretnie kwotę respondent przeznaczyłby w ujęciu rocznym, aby obiekt będący przedmiotem badania nie został zburzony. W tym przypadku nie wskazano wartości referencyjnej. Ankietowani oferowali albo konkretne wartości pieniężne, albo wartości procentowe względem kosztów utrzymania obiektu. Uśredniony wynik osób deklarujących konkretne kwoty wynosił 16,13 zł. Z kolei respondenci deklarujący swoje poparcie w wartościach procentowych średnio oferowali wartości około $1,67 \%$ całkowitych kosztów rocznego utrzymania obiektu. 


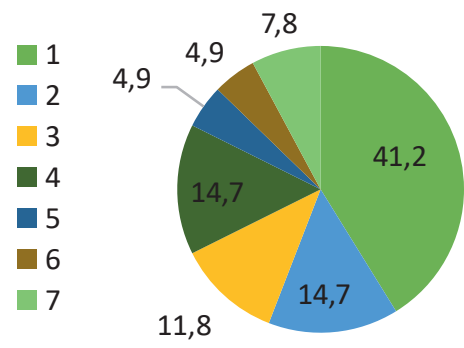

Wykres 1. Struktura odpowiedzi dla S1 Źródło: opracowanie własne

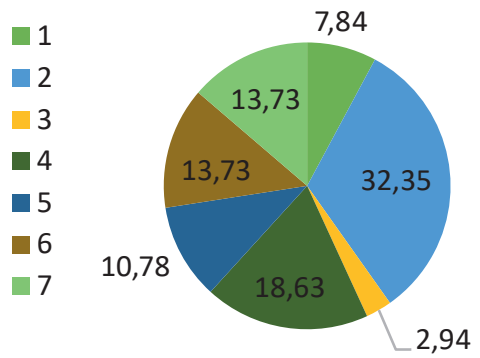

Wykres 3. Struktura odpowiedzi dla S5 Źródło: opracowanie własne

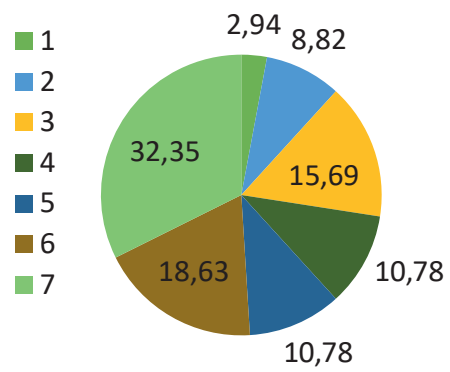

Wykres 5. Struktura odpowiedzi dla S3 Źródło: opracowanie własne
44,00

42,00

40,00

38,00

36,00

34,00

wartość średnia wartość wyceny referencyjna respondentów

Wykres 2. Wyniki badania SPM dla S1

Źródło: opracowanie własne

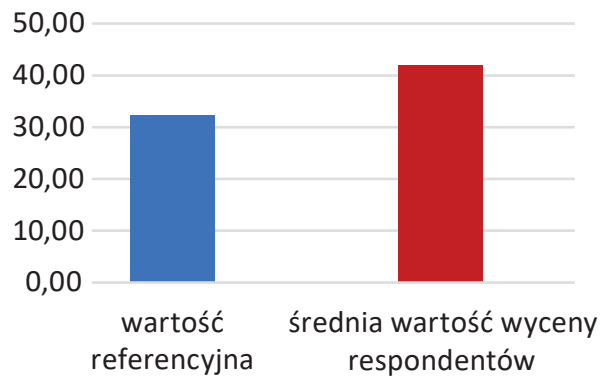

Wykres 4. Wyniki badania SPM dla S5

Źródło: opracowanie własne

200,00

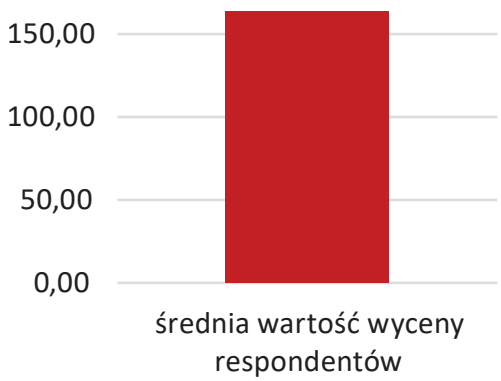

Wykres 6. Wyniki badania SPM dla S3

Źródło: opracowanie własne 


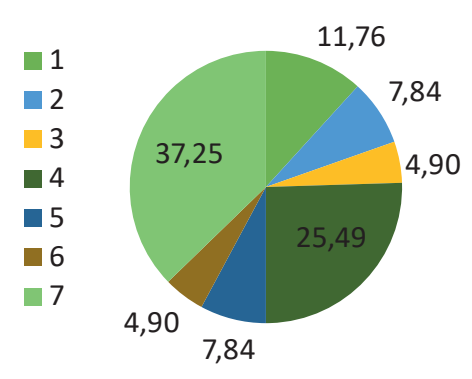

Wykres 7. Struktura odpowiedzi dla S4 Źródło: opracowanie własne

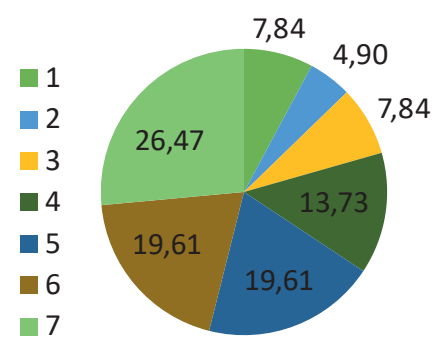

Wykres 9. Struktura odpowiedzi dla S2 Źródło: opracowanie własne

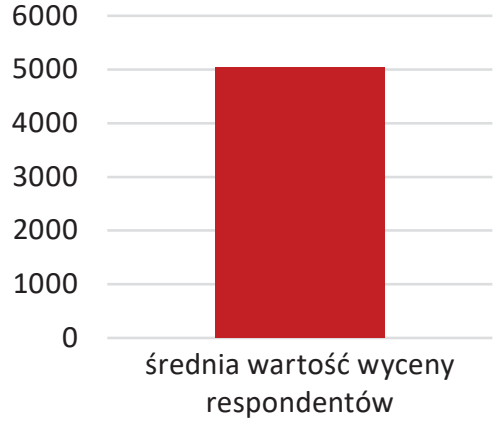

Wykres 8. Wyniki badania SPM dla S4 Źródło: opracowanie własne

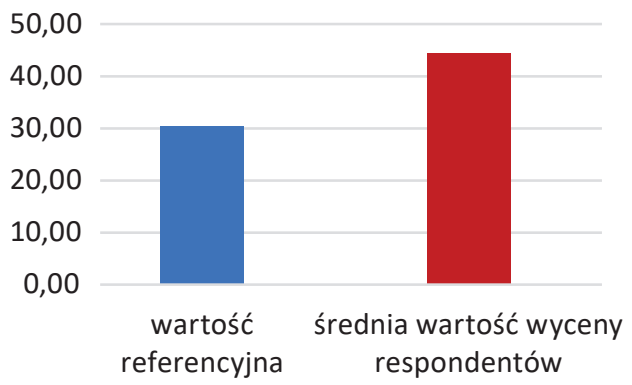

Wykres 10. Wyniki badania SPM dla S2 Źródło: opracowanie własne

\section{Wnioski i podstawowe wyzwania badawcze}

Wyniki badań dość jednoznacznie wskazują, że niezależnie od wieku i majętności respondentów historia i przeszłość zapisana w przestrzeni miasta w postaci szczególnej kompozycji urbanistycznej i specyficznej architektury jest ważna dla mieszkańców i ich przyszłości (potwierdzają to wyniki pierwszej i drugiej części badania ankietowego). Pomimo stosunkowo młodego wieku architektury modernistycznej i ciekawych, choć nie najbardziej uznanych i rozpoznawalnych obiektów w skali międzynarodowej lub krajowej, są one ważne dla lokalnej społeczności. Ważność ta nie tylko wyrażona jest w formie opinii, ale uwiarygodniona została też deklaracją potencjalnego zaangażowania finansowego respondentów w preferowane działania. Oczywiście tej deklaracji nie należy postrzegać dosłownie jako formy samoopodatkowania celowego mieszkańców, ponieważ jest to bardzo rzadko stosowany sposób finansowania inwestycji. Chodzi tutaj o identyfikację skali i poziomu przyzwolenia społecznego na wsparcie finansowe ze środków budżetowych miasta (w gruncie rzeczy podatków i opłat od mieszkańców). 
Preferencje wyrażone w odniesieniu do poszczególnych scenariuszy, wzmocnione deklaracją finansowego zaangażowania respondentów, pozwalają na sformułowanie wniosków pozytywnie weryfikujących hipotezę badawczą. Obiekt dziedzictwa kulturowego, charakteryzujący się wysokim poziomem użyteczności ma - po pierwsze - istotną wartość dla mieszkańców miasta. Po drugie, w kontekście wysokiego poziomu użyteczności, jego właściwości niematerialne, związane z kłopotliwym dziedzictwem historycznym, przestają determinować jego percepcję. Inaczej mówiąc, wyższy poziom użyteczności obiektu, ocenianej z perspektywy przeciętnego użytkownika, silnie oddziałuje na przekonanie o konieczności jego ochrony. Należy to interpretować w taki sposób, że wysoki poziom użyteczności nie determinuje wartości obiektu, a jedynie pozwala zauważyć i docenić inne walory niematerialne, dotychczas zdominowane efektem aureoli (halo).

Respondenci jednoznacznie opowiedzieli się za tym, iż „Central” w obecnym kształcie wart jest ochrony. Przy tym nie chodzi jedynie o zachowanie funkcji biurowo-handlowej, bo taką można by skuteczniej i efektywnie zorganizować w nowoczesnym budynku, ale o ochronę pełnego historycznego kształtu obiektu. Postulowana przyszłość obiektu z kłopotliwym dziedzictwem powinna być bezpośrednio związana z jego historią (jego kontynuacją obecnych funkcji - zarówno w sensie materialnym, jak i niematerialnym).

Można zatem sformułować ogólny wniosek, że utrzymując lub ponownie lokując funkcje użytkowe w obiektach trudnego dziedzictwa kulturowego, obniża się $\mathrm{w}$ istotnym zakresie percepcję trudnych faktów związanych z tym dziedzictwem. W kontekście przeprowadzonych badań wniosek ten można uznać za prawdziwy w odniesieniu do obiektów, których pierwotne funkcje miały charakter użytkowy. Akceptowalna jest przy tym stosunkowo niewielka ingerencja w zmiany o charakterze architektoniczno-budowlanym. Ponadto pozytywnej percepcji $\mathrm{w}$ tym zakresie towarzyszy afirmacja rozszerzonego spektrum funkcji obecnych w obiekcie. Większą wagę zaczynają przyjmować funkcje: edukacyjna, estetyczna, produkcyjna, usługowa i inne. W efekcie uwaga użytkownika zostaje w pozytywnym rozumieniu rozproszona na wielowątkową ocenę wartości zabytku, a nie tylko uproszczona i zawężona do skojarzeń z trudnym dziedzictwem historycznym. Stąd też kolejnymi wyzwaniami badawczymi w tym obszarze są: identyfikacja specyfiki i siły związku użyteczności funkcji obiektów trudnego dziedzictwa kulturowego z poziomem zaangażowania interesariuszy w strategię ich ochrony i zachowania wartości oraz weryfikacja bliźniaczej hipotezy badawczej w obiektach trudnego dziedzictwa historycznego o dominujących pozaużytkowych funkcjach pierwotnych. 


\section{Bibliografia}

Báez Montenegro A., Niklitschek Huaquin M., Herrero L.C. (2009), The valuation of historical sites: a case study of Valdivia, Chile, „Journal of Environmental Planning and Management”, vol. 52 , no. 1 , s. $97-109$.

Banaszkiewcz M. (2015), Trudne dziedzictwo a turystyka. O dysonansie dziedzictwa kulturowego, „Turystyka Kulturowa”, nr 11, s. 6-20.

Banaszkiewicz M., Semik Z. (2019), The 'dissonant' heritage of Nowa Huta's shelters: Between education and entertainment, „Tourism”, vol. 29, no. 1, s. 7-13.

Battilani P., Bernini C., Mariotti A. (2018), How to cope with dissonant heritage: a way towards sustainable tourism development, ,Journal of Sustainable Tourism”, vol. 26, no. 8, s. 1417-1433.

Bedate A., Herrero L.C., Sanz J.A. (2004), Economic valuation of the cultural heritage: application to four case studies in Spain, „Journal of Cultural Heritage”, no. 5, s. 101-111.

Borin E., Juno-Delgado E. (2018), The value of cultural and regional identity: an exploratory study of the viewpoints of funders and cultural and creative entrepreneurs, „Encatc Journal of Cultural Management \& Policy", vol. 8, issue 1, s. 17-26.

Borowski Z. (2016), Neoburżuazyjny anarchokonserwatzym, „Rzut +10”, nr 1, s. 54-64.

Bosek A., Mazurkiewicz L. (2015), O pewnej metodzie pomiaru nierynkowej wartości obiektu dziedzictwa kulturowego, „Ekonomia i Środowisko”, nr 1(52), s. 149-158.

Botton A. de (2006), Architektura szczęścia, Czuły Barbarzyńca Press, Warszawa.

Ciarkowski B. (2017), Architektura wypoczynkowa w służbie polityki - kłopotliwe dziedzictwo ośrodków wypoczynkowych z czasów Polski Ludowej, „Wiadomości Konserwatorskie”, nr 49, s. $19-25$.

Costa A.S., Lami I.M., Greco S., Figueira J.R., Borbinha J. (2019), A multiple criteria approach defining cultural adaptive reuse of abandoned buildings, [w:] A. G. Switzerland, S. Huber, M.J. Geiger, A.T. de Almeida (red.), Multiple criteria decision making and aiding: Cases on Models and Methods with Computer Implementations, International Series in Operations Research \& Management Science, vol. 274, Springer International Publishing, Cham, s. 193-220, https://doi.org/10.1007/978-3-319-99304-1_6

Dann G.M.S., Seaton A.V. (2001), Slavery, contested heritage and thanatourism, Hawthorn Hospitality Press, New York.

Dragićević Šešić M., Rogač Mijatović L. (2014), Balkan Dissonant Heritage Narratives (and Their Attractiveness) for Tourism, „American Journal of Tourism Management”, vol. 3(1B), s. 10-19.

Fredheim L.H., Khalaf M. (2016), The significance of values: Heritage value typologies re-examined, „International Journal of Heritage Studies”, vol. 22(6), s. 466-481.

Ingerpuu L. (2018), Socialist architecture as today's dissonant heritage: administrative buildings of collective farms in Estonia, „International Journal of Heritage Studies”, vol. 24, no. 9, s. $954-968$.

Jász B. (2018), Hidden Modernism: Architecture Theory of the Socialist Realist Gap, „Periodica Polytechnica Architecture", vol. 49(1), s. 92-97.

Kobyliński Z. (2011), Czym jest, komu jest potrzebne i do kogo należy dziedzictwo kulturowe?, „Mazowsze Studia Regionalne” nr 7, Mazowieckie Biuro Planowania Regionalnego w Warszawie, Warszawa, s. 21-41.

Light D. (2000), An Unwanted Past: contemporary tourism and the heritage of communism in Romania, „International Journal of Heritage Studies”, vol. 6(2), s. 145-160.

Matysiak K., Stępniak Ł. (2015), Chaos kontrolowany-Rozmowa z E. Rudnicka, ,Rzut +9”, nr 4, s. $28-38$.

Morse-Jones S., Mouratoc S., Ozdemiroglua E., Pearceb D., Provinsa A. (2008), Valuation of the historic environment: The scope for using economic valuation evidence in the appraisal of heritage related projects, „Progress in Planning”, no. 69, s. 131-175. 
Murzyn-Kupisz M. (2015), Values of cultural heritage in the context of socio-economics, [w:] B. Szmygin (red.), Heritage value assessment systems. The problems and the current state of research, Lublin University of Technology - Polish National Committee of the International Council on Monuments and Sites ICOMOS, Lublin - Warsaw, s. 147-160.

Nowakowska A., Guz J., Łaszkiewicz E. (2020), How is the multidimensional perception of modern architectural objects associated with their surroundings? An example of Warsaw Ochota urban railway station, [w:] Z. Gál, S.Z. Kovács, B. Páger (red.), Flows of Resources in the Regional Economy in the Age of Digitalisation. Proceedings of the 7th CERS Conference, Pécs, s. 323-336.

Ochkovskaya M., Gerasimenko V. (2018), Buildings from the socialist past as a part of a city's brand identity: The case of Warsaw, „Bulletin of Geography. Socio-economic Series”, vol. 39(39), s. $113-127$.

Pietrzyk-Kaszyńska A., Czepkiewicz M., Kronenberg J. (2017), Eliciting non-monetary values of formal and informal urban green spaces using public participation GIS, „Landscape and Urban Planning", no. 160, s. 85-95.

Polak E. (2018), Zacieranie granic i rozmywanie znaczeń jako jedna z tendencji współczesnych przemian cywilizacyjnych, „Annales Universitatis Mariae Curie-Skłodowska - Sectio K”, vol. XXV, no. 1, s. 25-38, http://doi.org/10.17951/k.2018.25.1.25

Purchla J. (2017), Kwestia dojrzałości, „Herito”, nr 29, s. 12-26.

Radzimirska W.A. (2011), Problemy ochrony $i$ konserwacji architektury czasów najnowszych na przykładzie warszawskich osiedli mieszkaniowych z lat 1950-1956, „Mazowsze Studia Regionalne", nr 7, Mazowieckie Biuro Planowania Regionalnego w Warszawie, Warszawa, s. $189-200$.

Sokołowicz M., Przygodzki Z. (2020), The value of ambiguous architecture in cities. The concept of a valuation method of 20th century post-socialist train stations, „Cities”, vol. 104, 102786, https://doi.org/10.1016/j.cities.2020.102786

Springer F. (2011), Źle urodzone. Reportaże o architekturze PRL-u, Wydawnictwo Karakter, Kraków.

Starzec P. (2015), Pamięć w Betonie, ,Rzut +9”, nr 4, s. 62-68.

Ustawa z dnia 1 kwietnia 2016 r. o zakazie propagowania komunizmu lub innego ustroju totalitarnego przez nazwy jednostek organizacyjnych, jednostek pomocniczych gminy, budowli, obiektów i urządzeń użyteczności publicznej oraz pomniki (Dz.U. z 2016 r., poz. 744).

Wejchert K. (1984), Elementy kompozycji urbanistycznej, Wydawnictwo Arkady, Warszawa.

Żylicz A. (2008), Wycena dóbr nierynkowych, zapis odczytu wygłoszonego na XLI Szkole Matematyki Poglądowej, Konkret i abstrakcja, s. 8-12, http://www.msn.uph.edu.pl/smp/msn/42 108-12.pdf [dostęp: 7.12.2020].

\title{
Estimating the Value of Dissonant Cultural Heritage. Valuation of Non-market Goods Using the Stated Preference Methods on the Example of a Modernistic Office and Commercial Complex
}

\begin{abstract}
The concept of dissonant cultural heritage is well recognized in the literature. It appears in several perspectives, in relation to shameful nation's history, fratricidal wars, totalitarian past, political regime, or aesthetic. In this article, subject of research is dissonant heritage that was the legacy of Soviet regime times 1945-1989 and at the same time - modernistic architecture, which is ambiguous in aesthetic valuation. Modernistic architecture (from socialistic era in polish history - called socmodernism) is visible in every polish city. It is used for residential, cultural, economic, public and other functions.
\end{abstract}


Over the decades these buildings have devaluated in physical and moral aspects. More and more often in public discourse appears opinion which claim about necessity of removal these part of unwanted history from polish cities landscape. The question arises whether the removal through destruction or general renovation of cultural heritage is the best way to urban renewal?

This particular work includes induction approach, basing on intentionally selected object, that indicate clear stigmatizing as well as historic features. The main aim of the work is to estimate the value of chosen socmodernistic object, which for many years was the most recognizable and dominant object in central area. The research challenge in this area was an appropriate selection and adaptation of valuation method and also results interpretation. Research were achieved basing on Stated Preference Methods (SPM). The subject of research is recognizable, distinctive for the city of Lodz and its residents, arbitrary chosen office and commercial complex - "Central". The study was conducted among users of the facility. Research results prove that if a building is characterized by a high level of usability, its value remains high despite the stigmas of dissonant cultural heritage.

Keywords: dissonant heritage, value of cultural heritage, stated preference methods (SPM), intangible assets of cultural heritage

JEL: R14, H41, O18

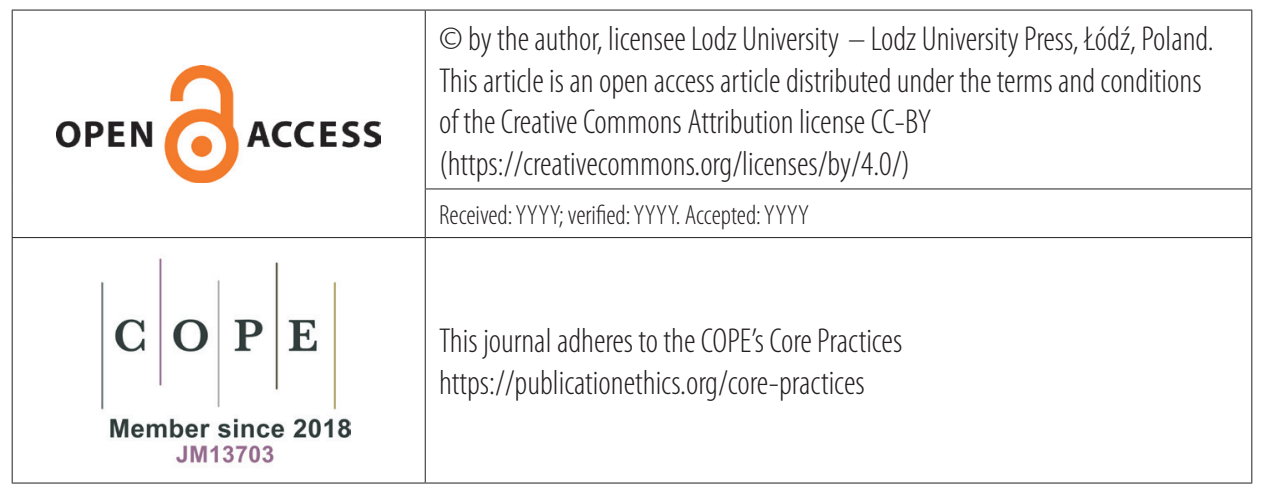

